\title{
International Financial Integration and Economic Growth in India: An Empirical Investigation
}

\author{
Nayia MAHAJAN* ${ }^{*}$ Satish VERMA**
}

\begin{abstract}
This study endeavors to estimate relationship between international financial integration and economic growth in India during 1981-2011. Apart from direct impact of international financial integration on growth, indirect impact (via financial development) has also been studied empirically. Models of co-integration and Vector Error Correction Model (VECM) have been applied to examine the relationships. The study observes that international financial integration affects the growth of the economy positively; and change in economic growth due to it through financial development is approximately 8.63 percent. The study also suggests that the structural reforms that took place in India in early nineties did not affect the existing relationship of global financial integration and economic growth significantly.
\end{abstract}

Key words: Globalization, Economic Growth, Financial Integration

JEL Code Classification: F3, O4, F39

UDC Code: $339.7+338.1(540)$

"Corresponding Author, Research Fellow, Punjab School of Economics, Guru Nanak Dev University, India. E-mail: nayiamahajan02@gmail.com.

${ }^{* *}$ Professor, RBI Chair, Centre for Research in Rural and Industrial Development, India. E-mail: svgndu@gmail.com 


\section{Introduction}

There is significant change in the financial structure of most of the countries in world since 1980s. The wave of financial liberalisation and globalization occurred in mid 1980s resulted into remarkable increase in capital flows among industrial and developing countries. A substantial increase in capital flows has been observed world-wide since 1991 which accelerated in 2000s due to financial liberalization (Osada \& Saito, 2010).

The integration of global financial system has its own stages. As its initial level, when capital is free to move globally, countries involved get the opportunities to explore highest returns by diversifying their portfolio. But as the level of integration increases, these benefits get contracted (Hoxa et al. 2009). As the matter of fact financial integration among the countries cannot be perfect due to different basic structure. Therefore, it becomes fruitful for the countries to open their capital accounts. There is wide spread view that increased international financial integration (whether in the form of capital account liberalization or with increase in capital inflows and outflows) has improved quality of domestic financial institutions and has helped increased economic growth and reduced volatility (Andersen \& Moreno, 2005). Various countries are involved in international financial integration because of its benefits.

There are some major channels though which financial opening could benefit countries that pursue it. One is consumption channel i.e. alleviation of capital scarcity and improved risk sharing. A country with access to world capital markets may indulge in consumption smoothing in the form of improved terms of trade and portfolio diversification ${ }^{\dagger 1}$. This channel may work by lowering the cost of capital thus adding to rate of economic growth. Second channel through which financial integration makes impact on real sector (economic growth) is production channel. As per this channel, when there seems an increase in production efficiency or specialization within the country through the medium of greater access to world capital market then this specialization in production amplifies sectoral shocks to various other countries. Levine (2001) in his study has documented as to how liberalizing restrictions on international capital transaction i.e. capital account liberalisation tended to enhance stock market liquidity and in turn accelerated economic growth by enhancing productivity growth. He has also empirically tested that entry of foreign entities in domestic banking system enhance productivity growth via increasing efficiency of the domestic financial system.

In theory, a number of direct as well as indirect channels are specified through which international financial integration facilitate to promote economic growth in developing countries (see Prasad et al., 2003). According to Edison et al. (2002),

\footnotetext{
${ }^{1}$ Portfolio Diversification means "investment in different asset classes and in securities of many issuers in an attempt to reduce overall investment risk and to avoid damaging a portfolio's performance by the poor performance of single security, industry (or country)".
} 
international financial integration may enhance efficiency of domestic financial system through competition and importation of various financial services. And, financial development enhances economic growth, which is well established in existing literature (see Mahajan \& Verma, 2014). Many studies (Gregorio, 1999; Levine, 2001; Arteta et al., 2001; Edison et al., 2002; Masten et al., 2008; Klein \& Olivei, 2008; Ang, 2009; Osada \& Saito, 2010; Chen \& Quang, 2012, etc) focused on the channels through which the international financial integration had been beneficial for enhancing growth in the participating economies. Among all the channels, financial development is important (see Gregorio, 1999; Levine, 2001; Klein \& Oleivi, 2008; Ang, 2009; Masten et al., 2011, etc).

The effects of global financial flows and international financial integration on domestic economic growth have been intensively debated. Many empirical studies (Fischer, 1997; Eichengreen, 2001; Stiglitz, 2003; Kose et al., 2006) are inconclusive and inconsistent about the results of this relationship. According to Edison et al. (2002), international financial integration is positively associated with growth of the economy. However, Kraay (1998) found weak relationship between financial openness and key macroeconomic indicators in a cross country analysis. Prasad et al. (2003) found that "Although capital inflows have been associated with high growth rates in some developing countries, but some have experienced decelerated growth rates, and also the financial crisis (due to external shocks) that have led the countries to bear substantial social and economic costs".

International Financial Integration can be treated as mixed blessings (Ray, 2012). "The World Bank, IMF and the WTO believe that international financial integration spur long-run economic growth in developing countries" (Levine, 2001). On the contrary, Krugman (1993) suggested that no doubt, developing countries that liberalize international financial interactions are likely to increase capital inflows but that helps momentarily and in small amount in long run economic growth. However, it cannot be denied that international financial integration in one way or the other helps boosting growth, albeit it appears to raise the frequency and severity of economic and financial crises. According to Mendoza et al. (2007), if international financial integration promotes financial development and allows for benefits such as technological diffusion, risk sharing, resource allocation etc, then, it can be beneficial for the countries involved. Osada and Saito (2010) has found positive impact of international financial integration in the form of FDI (Foreign Direct Investment) on economic growth, and also evidenced that the countries with good institutions and developed financial markets benefit more from financial integration $^{2}$. Schularick and Steger (2006) suggested that global financial integration promoted Countries economic growth significantly in the historical period, but such benefits were found absent in modern times.

\footnotetext{
${ }^{2}$ Countries in Western Europe and North America as well as those in East Asia are more likely to meet these conditions.
} 
As discussed above voluminous work has been done to empirically asses the linkages of international financial integration and economic growth for both developed as well as developing countries. But studies in the context of Indian economy (especially specific to India) are scarce. In India, financial system which was predominantly restricted to channel the resources from the surplus to deficit sectors until the 1980s attracted significant concerns from the global markets after financial sector reforms in eighties and early nineties. The immense increase in capital flows, particularly since 2000, has invoked the attention of the policy makers to ascertain the impact of this integration on the macroeconomic policy, growth rate, macroeconomic stability of the Indian economy etc. Present study accordingly, is aimed at assessing if integration of Indian financial system with rest of the world has impacted growth of the economy. Direct as well as indirect (via financial development) relation of international financial integration and economic growth while incorporating the influence of structural reforms on the said relationship (if exists) has been studied.

\section{Database, Variables and Tools used for Analysis}

This study makes use of time series data from 1981 to 2011 sourced from the dataset constructed by Lane and Milesi-Ferretti (2012); World Development Indicators by World Bank; Handbook of Statistics on Indian Economy by Reserve Bank of India; and International Financial Statistics by International Monetary Fund (IMF). An attempt has been made to find out whether the international financial integration by improving domestic financial markets helps in boosting growth of the economy! The direct impact of international financial integration on growth of the Indian economy has also been studied. For the purpose, variables enlisted in Table 1 have been used.

Table 1. Summary of variables

\begin{tabular}{ll}
\hline Variable & Description \\
\hline GDP & $\begin{array}{l}\text { Real growth } \\
\text { measure of growth. }\end{array}$ \\
\hline IFI & $\begin{array}{l}\text { An index to measure International Financial Integration of India with rest of } \\
\text { the world. It is the ratio of foreign assets and liabilities (both portfolio } \\
\text { equity and FDI) to GDP }\end{array}$ \\
\hline IFD & $\begin{array}{l}\text { An index to represent the depth of Indian financial system i.e. Index of } \\
\text { Financial Development }\end{array}$ \\
\hline IV (Interaction & $\begin{array}{l}\text { A variable generated by adding the index for financial development with } \\
\text { that of international financial integration and used as an interaction of IFI } \\
\text { and IFD }\end{array}$ \\
\hline D1 & $\begin{array}{l}\text { Dummy Variable for structural break in 1991 when India adopted policies } \\
\text { of liberalization, privatization and globalization (i.e. intensive phase of } \\
\text { liberalisation) }\end{array}$ \\
\hline
\end{tabular}

\footnotetext{
${ }^{3}$ Real indicates Gross Domestic Product (GDP) at constant prices (2004-05).
} 
Various time series econometric techniques such as Engle and Granger (1987) bivariate and Johansen (1990) multivariate co-integration approaches and Vector Error Correction Model (VECM) were performed along with diagnostic tests (Unit Root, LM (Lagrange Multiplier), J-B (Jarque-Bera)) to analyze the interlinkages.

\subsection{Proxy for International Financial Integration}

There are broadly two measures to proxy for International Financial Integration (IFI). First, de jure indicators that are concerned with government policies and regulatory framework restricting capital account transactions (Chen \& Quang, 2012). Second, de facto indicators that are intended to assess actual transmission of international capital flows. These quantitative indicators, based on direct observation of cross-border capital flows, are less prone to measurement errors than the rule based indicators (Chen \& Quang, 2012).

Following Lane and Milesi-Ferretti (2003), in the present study, de facto (volume based) indicators have been preferred because de jure (rule based) indicators have several drawbacks. Firstly, de jure indicators are time variant while de facto are highly persistent. Second, rule based indicators may not be reliable to reflect the actual financial openness; that may be because of poor correlation of these indicators to the actual flows received in developing countries (Prasad et al. 2003)

In empirical research, either gross measure of capital inflows and outflows or stock measure of foreign assets and liabilities (accumulated over time) has been used. Present study utilized the stock data of international flows computed by Lane and Milesi-Ferretti (2012) to formulate the index proxy for international financial integration. These data are more accurate than gross capital flows as these are less sensitive to short run factors. These data are also carefully corrected for price and exchange rate fluctuations. The index constructed as proxy for international financial integration is:

$I F I_{t}=\left(P A_{t}+F D I A_{t}+P L_{t}+F D I L_{t}\right) / G D P_{t}$

Where $\mathrm{IFI}_{\mathrm{t}}$ is an index proxy for international financial integration at time $t$ and $\mathrm{PA}_{t}$ and $P L_{t}$ are portfolio assets and liabilities respectively of the country at time $t$. Similarly FDIA $_{t}$ and FDIL $_{t}$ are FDI (Foreign Direct Investment) assets and liabilities respectively.

\subsection{Index for Financial Development}

For measuring the extent of financial development in the economy, financial development index (IFD) has been constructed. Six proxy variables (which have been utilized in literature ${ }^{4}$ ) representing both money and capital markets have been used to formulate it. These variables are:

- Total banking business (ratio of (total credit + total deposits) to GDP),

\footnotetext{
${ }^{4}$ See studies like Demetriades and Hussein (1996), Kelin and Olivei (2008), Lee and Chang (2009), Wolde-Rufael (2009), Hassan et al. (2011), Kar et al. (2011) etc.
} 
- Credit-deposit ratio,

- Rate of monetization (M3/GDP),

- Value traded ratio (value of stocks traded/GDP),

- Turnover ratio (value of stocks traded/stock market capitalization),

- Ratio of credit to private sector to GDP.

Among these, first, second and sixth variables represent banking activities; third variable is intended to capture role of money supply in the economy; and rest are specific to stock market. Instead of using these various correlated variables, a composite variable called Index for Financial Development (IFD) was made, following the technique of Principal Component Analysis (PCA). This index is based on factor loadings given by principal components (those explaining maximum variance in the data). Appendix Table 1 presents the results of Principal Component Analysis which suggest that about $70 \%$ of total variance is explained by the first component. Therefore, by adding the multiplication of actual values of five variables and their corresponding factor loadings obtained from first principal component (PC1), the composite index (IFD) of financial development was constructed.

\section{Empirical Estimates}

Empirical estimates have been presented in three parts. First, analysis of interaction of IFI, financial development and economic growth in India with the help of Johansen multivariate technique of co-integration and Vector Error Correction Mechanism (VECM); second, direct and indirect role of IFI in economic growth by developing three different models (using Engle-Granger cointegration approach); and the third examines the indirect impact of IFI on economic growth via financial development using an interaction variable.

\subsection{Relationship among IFI, IFD and GDP}

To find out long run inter linkages of IFI, financial development and economic growth, Johansen co-integration approach has been applied. The idea behind using this technique is that when the considered time series variables are not stationary at levels, the simple regression may give spurious results that disturb the accuracy of estimates of parameters. With differencing, stationarity of time series variables can be achieved but that does not lead to a long run solution. To resolve the issue, the most useful is the methodology of co-integration and Error Correction Mechanism (ECM). The estimation procedure in this approach involves, first, to check the order of integration of the considered variables (see Asteriou \& Hall, 2007). And, if all the variables are integrated of same order i.e. (I(1)), existence of long run relationship between these time series variables can be tested.

Granger (1981) introduced a remarkable link between non-stationary processes and the concept of long-run equilibrium, called co-integration. As per this approach, if all the time series variables are not stationary at their levels, then they 
are said to be cointegrated if any linear combination of these non-stationary variables provides a series which is stationary at levels. This type of relationship is known as long-run relationship between the variables (Granger, 1981). Engle and Granger (1987) further formalized this concept by introducing a very simple test for the existence of cointegrating (i.e. long-run equilibrium) relationships. Under this, after testing for the existence of cointegrtion, in case it exists, it becomes necessary to form the model in the equivalent ECM (Error Correction Model) to get causal relationship between time series variables. The Granger representation theorem establishes that any cointegrated series have an ECM and its converse is also true (see Engle \& Granger, 1987). Therefore, cointegration is a necessary condition for an ECM to hold (see Engle \& Granger, 1991).

Thus, as a preliminary investigation, Augmented Dickey-Fuller (1979) and PhilipPerron (1988) tests of unit root $^{5}$ has been worked out for all series to examine the order of integration. The results are presented in Table 2. It is evident from the table that all the three variables used are integrated of order I (1) under both the test statistics (ADF and P-P). In other words, unit root is present in data when checked at levels, i.e. series are non-stationary at levels but stationary at first difference.

\section{Table 2. Results of unit root test}

\begin{tabular}{ccccccc}
\hline \multirow{2}{*}{ Variable } & \multicolumn{3}{c}{ ADF test statistic } & \multicolumn{3}{c}{ P-P test Statistic } \\
\cline { 2 - 7 } & At Levels & $\begin{array}{c}\text { At First } \\
\text { Differences }\end{array}$ & Result & At Levels & $\begin{array}{c}\text { At First } \\
\text { Differences }\end{array}$ & Result \\
\hline GDP & -0.3967 & $-8.8677^{*}$ & $\mathrm{I}(1)$ & -0.9456 & $-18.3289^{*}$ & $\mathrm{I}(1)$ \\
\hline IFI & 0.1723 & $-6.1539^{*}$ & $\mathrm{I}(1)$ & -2.1725 & $-6.3817^{*}$ & $\mathrm{I}(1)$ \\
\hline IFD & -0.6347 & $-3.7300^{*}$ & $\mathrm{I}(1)$ & 0.9456 & $-3.8121^{*}$ & $\mathrm{I}(1)$ \\
\hline
\end{tabular}

Note: ' ${ }^{* \prime}$ shows significance at $5 \%$. Null hypothesis $\left(\mathrm{H}_{\mathrm{o}}\right)$ is that there is unit root in the series.

Source: Authors' calculations

After fulfilling this condition for co-integration analysis, a model including above three variables (GDP, IFI IFD) was estimated with Johansen (1991) multivariate approach with D1(dummy variable) as exogenous variable for incorporating the impact of 1991 structural changes in the economy.

The Johansen cointegration approach has been criticized for being sensitive to the selection of lag length. Therefore, to perform the co-integration analysis and hence VECM estimates for short run dynamics, lag length 2 has been selected on the basis of Likelihood Ratio (LR) test and AIC criterion by estimating VAR (Vector Autoregressive) for various lag lengths for our model ${ }^{6}$.

The next step in VECM modeling is the selection of appropriate model for cointegration analysis which attains both short run and long run properties. In

\footnotetext{
${ }^{5}$ See Asteriou and Hall, 2007, p. 288 for details on Unit Root Tests

${ }^{6}$ The model which maximizes the values of the log-likelihood function and minimizes the AIC (Akaike Information Criterion) has been selected for optimal lag length
} 
general, five distinct models are offered in literature on cointegration analysis: (i) no intercept or trend in cointegrating equation (CE) and VAR; (ii) intercept (no trend) in CE, no intercept or trend in VAR; (iii) intercept in CE and VAR, no trends in CE and VAR; (iv) intercept in CE and VAR, linear trend in CE, no trend in VAR; and (V) intercept and quadratic trend in the CE intercept and linear trend in VAR. The problem is which one of the five different models is appropriate in testing for cointegration. The first and the fifth are not that realistic. Therefore, the problem reduces to a choice of one of the three remaining models. Johansen (1992) suggests the need to test the joint hypothesis of both the rank order and the deterministic components, applying the so called Pantula principle. The Pantula principle involves the estimation of all three models and the presentation of the results from the most restrictive hypothesis (i.e. $r=$ number of cointegrating relations $=0$ and model 2 ) through the least restrictive hypothesis (i.e. $r=$ number of variables entering the VAR-I or $n-I$ and model 4$)$. The model selection procedure then comprises moving from the most restrictive model, at each stage comparing the trace test statistic to its critical value, stopping only when we conclude for the first time that the null hypothesis of no co-integration is not rejected.

Results for model 2, 3 and 4 are presented in Table 3. As per the Pantula principle, model 2 (incorporating either intercept or trend) was selected the best suited for the data set because, first time it was for model 2 that null hypothesis was not being rejected and that was in case of one co-integrating relation.

\section{Table 3.The Pantula principle test results}

\begin{tabular}{cccc}
\hline Hypothesized No. of & \multicolumn{3}{c}{ Trace Statistic } \\
\cline { 2 - 4 } Co integration Relations & Model 2 & Model 3 & Model 4 \\
\hline None & $38.8422^{*}$ & $34.4987^{*}$ & $52.8256^{*}$ \\
\hline At Most 1 & 10.6281 & 7.2111 & 11.4828 \\
\hline At Most 2 & 0.7871 & 0.0462 & 4.1729 \\
\hline
\end{tabular}

Note: ${ }^{\prime * \prime}$ indicates the rejection of null hypothesis

Source: Authors' calculations

After choosing appropriate model, the presence of cointegrating relation among the considered variables was examined. For testing the long run equilibrium relationship, it is necessary to indentify the number of cointegrating vectors which is possible through determining the rank of matrix $\pi$. According to Johansen and Juselius (1990), there are two methods for determining the number of cointegrating relations, named Lambda Max Test and Trace test. Both involve estimation of the matrix $\Pi$ which is $k \times k$ matrix with rank $r$. The procedures are based on propositions about eigen values. The results of both the test statistics are presented in Table 4. Both the Trace as well as Max-Eigen value statistic suggest the existence of one co-integrating relationship; and thus confirmed the existence of long run relation between IFI, financial development and economic growth in India. As per diagnostic analysis, both the residual test statistics (LM and J-B) are found insignificant. That shows, our model is free from the problem of 
International Financial Integration and Economic Growth in India: An Empirical Investigation

autocorrelation in the estimated residuals and these (residuals) are not multivariate normal (depicted by insignificant J-B test statistic).

Table 4: Determining the rank of co-integrating matrix

\begin{tabular}{|c|c|c|c|c|c|}
\hline \multicolumn{2}{|c|}{ Hypotheses } & \multirow{2}{*}{$\begin{array}{c}\text { Maximum } \\
\text { Eigen statistic }\end{array}$} & \multirow{2}{*}{$\begin{array}{c}5 \% \\
\text { critical value }\end{array}$} & \multirow{2}{*}{$\begin{array}{c}\text { Trace } \\
\text { statistic }\end{array}$} & \multirow{2}{*}{$\begin{array}{c}5 \% \\
\text { critical value }\end{array}$} \\
\hline $\mathrm{H}_{0}$ & $\mathrm{H}_{1}$ & & & & \\
\hline$r=0$ & $r \geq 1$ & $28.2141^{*}$ & 22.2996 & $38.8422 *$ & 35.1928 \\
\hline$r \leq 1$ & $r \geq 2$ & 9.84099 & 15.8921 & 10.6281 & 20.2618 \\
\hline$r \leq 2$ & $r \geq 3$ & 0.7871 & 9.1645 & 0.7871 & 9.1645 \\
\hline
\end{tabular}

Residual

LM Test Statistic $(1)=11.3547(0.3225)$

Diagnostic Test Jarque-Bera Test Statistic $=5.6517(0.4633)$

Note: ${ }^{\prime * \prime}$ indicates significance at $5 \%$. Figures in the parentheses are P-value for the respective test statistic. Source: Authors' Calculations

To find out short run dynamics in relationship among these variable, estimates of Vector Error Correction Mechanism (VECM) are obtained. Table 5 presents the results for VECM including three variables, i.e. IFI, Index of financial development and economic growth proxied with real GDP growth rate.

Table 5: Results for vector error correction model (short run analysis)

\begin{tabular}{cccc}
\hline & $\Delta(\mathrm{GDP})$ & $\Delta(\mathrm{IFI})$ & $\Delta$ (IFD) \\
\hline Error Correction term & $-0.8913^{*}[-2.2438]$ & $0.0141^{*}[2.9108]$ & $0.2514[0.8309]$ \\
\hline$\Delta(\mathrm{GDP}(-1))$ & $0.0318[0.1039]$ & $-0.0084^{*}[-2.2657]$ & $0.0526[0.2260]$ \\
\hline$\Delta(\mathrm{GDP}(-2))$ & $0.1847[0.8419]$ & $-0.0017[-0.6287]$ & $0.1313[0.7858]$ \\
\hline$\Delta(\mathrm{IFI}(-1))$ & $-30.8612^{*}[-1.7847]$ & $-0.9189^{*}[-0.4369]$ & $1.1231[0.0853]$ \\
\hline$\Delta(\mathrm{IFI}(-2))$ & $-40.6441^{*}[-2.2745]$ & $-0.6904^{*}[-3.1775]$ & $8.7929[0.6461]$ \\
\hline$\Delta(\mathrm{IFD}(-1))$ & $0.2349[0.8724]$ & $0.0106^{*}[3.2448]$ & $0.3521[1.7163]$ \\
\hline$\Delta$ (IFD(-2)) & $0.1105[0.3304]$ & $0.0116^{*}[2.8501]$ & $0.2293[0.9007]$ \\
\hline Dummy & $-0.8628[-0.9263]$ & $0.0148[1.3041]$ & $1.2130[1.7098]$ \\
\hline
\end{tabular}

Note: Figures in the parentheses are t-values. ${ }^{~}{ }^{* \prime}$ indicates significance at $5 \%$ level.

Source: Authors' Calculations

As per rules, when co-integrating relation exists in the multivariate system, there are as many residual series. These are called Error Correction Terms (ECTs) which are presented in their lagged form as exogenous variable in VECM. Results reveal that ECT for only GDP as the dependent variable is negative and significant. It suggests the convergence towards long run equilibrium path and any disequilibrium in GDP in one period is expected to be corrected in the next period, i.e. in one year and one month (1/0.8913). As far as short run relationship is concerned, there exists relationship between IFI and GDP and that of IFI with financial development. It suggests the presence of short run tendencies of IFI towards financial deepening and economic growth.

Thus, it is confirmed that in case of India for short period also, international financial integration improves economic growth and facilitated further financial deepening of domestic financial system. However, Kim et al. (2012) found in cross 
country analysis (while studying relationship between financial openness and growth) that there are short run pains and long run gains from international financial integration. And, Levine (2001) opined that "international financial integration can promote economic development by encouraging improvement in domestic financial system with positive ramification for long run productivity growth". The dummy variable taken to capture the influence of structural reforms in early nineties is insignificant, thereby suggesting no impact of structural changes on the relationship between IFI, financial development and economic growth.

\subsection{Direct and Indirect Relation}

This section examines direct as well as indirect impact of IFI on economic growth of India. Granger Co-integration Approach (see Engle \& Granger, 1987) has been utilized to test the relationship. According to this approach, if time series variables are integrated of same order, then the next step is to estimate the long-run equilibrium relationship via estimating co integrating regression equation and obtain the series of estimated residuals. In present study, following three co integrating equations have been estimated and consequently three residuals $\left(\mu_{\mathrm{to}}\right.$, $\left.\mu_{\mathrm{t} 1}, \mu_{\mathrm{t} 2}\right)$ are generated.

Model I GDP $=\alpha_{0}+\beta_{0} I F I+\gamma_{0} D 1+\mu_{\mathrm{t} 0}$

Model II IFD $=\alpha_{1}+\beta_{1}$ IFI $+\gamma_{1} D 1+\mu_{\mathrm{t} 1}$

Model III GDP $=\alpha_{2}+\beta_{2}$ IFD $+\gamma_{2} D 1+\mu_{\mathrm{t} 2}$

For each of these models, corresponding Error Correction Model (ECM) has been run as given below

$\Delta \mathrm{Y}_{\mathrm{it}}=$ constant $_{\mathrm{i}}+\beta_{\mathrm{i}} \Delta \mathrm{X}_{\mathrm{it}}+\prod_{i} \mu_{t-1}+\alpha_{\mathrm{i}} \mathrm{D}_{\mathrm{i}}+\mathrm{e}_{\mathrm{t}}$

Where $\mu_{t-1}$ is the lagged value of residual generated from co-integrating equation and $D_{i}$ captures the influence of structural break in 1991.

Model I is an attempt to find direct long run relationship (if exists) between IFI and economic growth (GDP). Gregorio (1999) in a cross country analysis (24 countries) found no evidence of direct effect of financial integration on economic growth. Results for Model I presented in Table 6 show that a positive and significant long run relation is present during the time considered.

\section{Table 6: Results of co-integrating regression for Model I}

\begin{tabular}{lccc}
\hline Coefficients & Values & t-statistic & P-Value \\
\hline Constant $\left(\mathrm{a}_{0}\right)$ & $5.4239^{*}$ & 8.5110 & 0.0000 \\
\hline $\mathrm{IFI}\left(\beta_{0}\right)$ & $10.9662^{*}$ & 3.1211 & 0.0042 \\
\hline $\mathrm{D} 1\left(\gamma_{0}\right)$ & -0.5631 & -0.6116 & 0.5458 \\
\hline ADF test statistic for residual series $\left(\mu_{\mathrm{t} 0}\right)$ & $-1.0729^{*}$ & -5.7356 & 0.0076 \\
\hline Note: ${ }^{\prime *}$ indicates significance at $5 \%$. Source: Authors' calculations & &
\end{tabular}

It is indicated by significant $\beta_{0}$ and stationary residual $\left(\mu_{0}\right)$. Thus, the role of international financial integration in the form of capital inflows and outflows in 
economic growth cannot be denied. For comprehending details of short run dynamics, Error Correction Method has been applied. Results of this are presented in Table 9 along with other Models. Results show that, in short run also, positive relationship exists between these two variables. The negative significant adjustment coefficient ( $\Pi$ ) indicates that any short run discrepancies (if exist) would be resorted in the long run.

In theory, when channels through which international financial integration boost economic growth are considered, one among them is deepening of domestic financial markets. Taking this theoretical base, Levine (2001) evaluated that international financial openness ${ }^{7}$ accelerates economic growth by improving the functioning of domestic financial markets and the banks. Kose et al. (2003) also observed that indirect impact of international financial integration on economic growth is realized mainly through financial development. Many other studies (Gregorio (1999), Klein and Olivei (2008), Ang (2009) and Masten et al. (2011)) have examined the relationship of international financial integration and economic growth through its impact on development of domestic financial markets. Gregorio (1999), in an exercise of assessing the interactions among financial deepening, international financial integration and growth, concluded that beneficial effects of IFI flow mainly through fostering the development of financial system. Similar conclusions were drawn by Klein and Olevei (2008) in case of 21 OECD and 74 non OECD countries. However, results of their studies are mainly driven by developed countries. Moreover, Masten et al (2011) in their study confirmed that in addition to direct effect, there also exists indirect positive effect of international financial integration on economic growth which is realized through development of domestic financial markets. Thus, in the light of observed facts in the literature, the present study incorporated this indirect impact, i.e. impact of IFI on economic growth via financial development. For the purpose, Model II and Model III were evaluated. Model II examines the impact of IFI on financial development. Results are reported in Table 7.

\section{Table 7: Results of co-integrating regression for Model II}

\begin{tabular}{lccc}
\hline Variables & Coefficients & t-statistic & P-Value \\
\hline Constant $\left(\alpha_{1}\right)$ & $31.9346^{*}$ & 22.1549 & 0.0000 \\
\hline $\mathrm{IFI}\left(\beta_{1}\right)$ & $134.9941^{*}$ & 16.98642 & 0.0000 \\
\hline $\mathrm{D} 1\left(\gamma_{1}\right)$ & 3.1539 & 1.5145 & 0.1411 \\
\hline ADF test statistic for residual series $\left(\mu_{\mathrm{t} 1}\right)$ & $-1.3120^{*}$ & -3.1877 & 0.0026 \\
\hline
\end{tabular}

Note: ${ }^{* \prime \prime}$ indicates significance at level of $5 \%$. Source: Authors' calculations

These empirical results reveal that long run equilibrium relation between the IFI and financial development is present, as ADF test statistic for residual $\left(\mu_{1}\right)$ is significant. That means, international financial integration has statistically significant impact on development of domestic financial markets in India.

\footnotetext{
${ }^{7}$ Which is initial stage of international financial integration.
} 
But, short run relation in this case is absent (see Table 9). That may be because, as domestic financial markets get linked with international markets through any of the mediums, it is not the immediate outcomes of this connectivity that domestic markets grow with openness. Development of financial system is a long term process which is not realized at once. Kim et al. (2012) in their study recognized that though financial opening strengthens financial deepening and institutional development in long run which ultimately affects macroeconomic growth, but it also increases the chances of financial crises (shocks due to financial opening) that may have short-run repercussions. Thus, there may be a trade-off between the adverse short-run and beneficial long-run effects of financial integration.

In the second step of analyzing indirect relation, Model III has been evaluated which ascertains the role of financial development (which is one of the consequences of IFI) in the growth of the economy during the study period. Results for Model III are presented in Table 8.

Table 8: Results of co-integrating regression for Model III

\begin{tabular}{lccc}
\hline Variables & Coefficients & t-statistic & P-Value \\
\hline Constant $\left(\alpha_{2}\right)$ & $3.4137^{*}$ & 3.0781 & 0.0046 \\
\hline $\operatorname{IFD}\left(\beta_{2}\right)$ & $0.0639^{*}$ & 2.4396 & 0.0213 \\
\hline $\mathrm{D} 1\left(\gamma_{2}\right)$ & -0.4310 & -0.4293 & 0.6709 \\
\hline ADF test statistic for residual series $\left(\mu_{\mathrm{t} 2}\right)$ & $-1.1207^{*}$ & -5.9875 & 0.0000 \\
\hline
\end{tabular}

Note: ${ }^{* \prime}$ indicates significance at level of $5 \%$. Source: Authors' calculations

There is strong belief among economists and analysts that financial development plays important role in economic growth. Many studies in the literature have recognized positive and significant relation between these two (see Mahajan and Verma, 2014). In our case, results confirm the positive, significant and long run relation of financial development and economic growth of the nation. While examining the short run relation through Error Correction Model (ECM), Table 9 reveals absence of it.

This is in line with the study by Calderón and Liu (2003) who in case of 109 high, middle and low income economies (including India) empirically found that impact of financial deepening on real sector is realized with time lag. Also Ahmad and Ansari (1998) and Fase and Abma (2003) discarded short run relationship in their studies. But, negative and significant adjustment coefficient ( $\Pi$ ) confirms the presence of adjustment in the system that leads to long run equilibrium, which is supported by the results in the study by Mahajan and Verma (2014).

Table 9: Empirical estimates of Error Correction Models

\begin{tabular}{lccc}
\hline Variables & Model I & Model II & Model III \\
\hline Constant & -0.0428 & 0.8446 & 0.0208 \\
\hline Independent variable & $25.0765^{*}$ & 11.5988 & -0.0544 \\
\hline Dummy (D1) & -0.1578 & 1.2819 & 0.2373 \\
\hline$\prod$ (Adjustment Coefficient) & $-1.0309^{*}$ & -0.0369 & $-0.1089^{*}$ \\
\hline Note: ${ }^{* \prime}$ indicates significance at level of 5\%. Source: Authors' calculations &
\end{tabular}


The dummy variable taken for structural break is insignificant in all the models, hence showing that structural reforms in 1991 could not impact significantly the existing relationship of international financial integration with financial development and economic growth. This is because the mild Liberalization phase in India had begun in 1981 with the SDR 5 billion loan from the International Monetary Fund (IMF). The loan was conditional on an "adjustment programme" which aimed at limiting the constraints against the growth of private sector; and to increase the leverage of the foreign sector (Verma \& Arora, 2010). Virtually, liberalizing the terms and conditions for foreign capital had been started before 1990s which continued in a sporadic manner till nineties. The economic reforms initiated in 1991 under "Structural Adjustment Programme (SAP)", were actually another phase of liberalization which is called 'Intensive-Liberalization phase' (Verma \& Arora, 2010). As the study period starts from 1981, the estimates made therefore have not shown any statistically significant influence of structural reforms of early 1990s.

Furthermore, following Gregorio (1999) and Klein and Olivei (2008), in order to gauge the extent of the impact of IFI on economic growth via financial development, the product of the coefficient of change in financial development due to change in IFI represented by $\beta_{1}$ in Model II and that of change in economic growth due to change in financial development represented by $\beta_{2}$ in model III were considered. Using this method, it is estimated that change in economic growth due to international financial integration through financial development is approximately $8.63 \%$. Thus, estimates from several empirical specifications used in this section suggest that international financial integration in the form of capital inflows and outflows makes statistically significant contribution to economic growth, both directly as well as via development of domestic financial system.

\subsection{Interaction Model}

Finally, in this part, with the help of another model, some empirical evidence of indirect impact of financial integration on economic growth using interaction variable is given. Following Ang (2009), interaction of IFI, economic growth and financial development was examined by introducing an interaction variable. Table 10 reveals the result for this mechanism.

Table 10: Estimation of number of co-integrating relations

\begin{tabular}{|c|c|c|}
\hline \multirow{2}{*}{ Test Statistics } & \multicolumn{2}{|c|}{ Co-integrating Relations } \\
\hline & Model A (GDP, IFI, D1) & Model B (GDP, IFI, IV, D1) \\
\hline Trace Statistics $\left(\lambda_{\text {trace }}\right)$ & $\begin{array}{c}\text { None* } \\
\text { Atmost } 1\end{array}$ & $\begin{array}{c}\text { None* } \\
\text { Atmost } 1^{*} \\
\text { Atmost } 2\end{array}$ \\
\hline $\begin{array}{l}\text { Max-Eigen value } \\
\text { statistic }\left(\lambda_{\max }\right)\end{array}$ & $\begin{array}{c}\text { None* } \\
\text { Atmost } 1\end{array}$ & $\begin{array}{c}\text { None* } \\
\text { Atmost 1* } \\
\text { ATmost } 2\end{array}$ \\
\hline
\end{tabular}

Note: * indicates significance at level of 5\%. Source: Authors' Calculations. 
Results for both of the test statistics (Trace and Maximum-Eigen value) in case of Model A as well as Model B are given where model A studies the relation between GDP and international financial integration in the light of 1991 reforms. Whereas in Model B, an additional interaction term (as an exogenous variable) is included which incorporates the effect of financial development in explaining role of IFI in GDP (interaction variable is calculated by adding the index for financial development with that of IFI). Results clearly show that when interaction variable is added in the model (Model B), number of co-integrating relations are two (through both test statistics) as compared to the one in Model $A$ in which there is no such variable. It indicates that financial development plays role in reaching the positive effects of IFI to growth. This analysis is also for the robustness of the results obtained in previous section.

\section{Conclusion and Suggestions}

The overall conclusion that emerges from the study is that international financial integration in the form of capital inflows and outflows significantly affect economic growth of the nation both in short as well as long run (supported by Ray, 2012). And the change in economic growth due to international financial integration through financial development is approximately $8.63 \%$ as per analysis. It is, thus, concluded that where in the present scenario domestic financial market imperfection and institutional weakness is the main problem, international financial integration helps in improving domestic financial system in the form of efficient capital market, banking system and monetary system. It supports the view point that the entries of various foreign banks and other financial entities or any other form of capital inflows are helpful in attaining higher level of efficiency, hence development of the financial system. Thus, capital flows should be welcomed in the economy, provided strong vigilance and prudential supervision is maintained by the apex institutions.

Moreover, the relationship of financial development with economic growth has been found significant in long run. But, in the short run, the relationship among the variables is not significant. This has the implication that in the short run financial development which is outcome of the international financial integration is not beneficial for the India but its fruits can be availed by the economy only in long run. Thus, it is inferred that accruing the benefits of financial development and that of global financial integration is a gradual and long run process. Hence, to maintain rapid economic growth, government has to deepen foreign capital inflow as well as capital outflow and undertake essential measures to strengthen the long run relationship between financial integration, financial development and economic growth in India. 
International Financial Integration and Economic Growth in India: An Empirical Investigation

\section{References}

Ahmed, S. M., \& Ansari M. I. (1998). Financial Sector Development and Economic Growth: The South Asian Experience. Journal of Asian Economics, 9(3), 503-517. http://dx.doi.org/10.1016/S1049-0078(99)80100-6

Andersen, P., \& Moreno R. (2005). Financial Integration: An Overview. BIS Working Papers No. 23.

Ang, J. B. (2009). Financial Development and the FDI-Growth Nexus: The Malaysian Experience. Applied Economics, 1595-1601. http://dx.doi.org/10.1080/00036840701222553

Arteta, C., Eichengreen B., \& Wyplosz C. (2001). When Does Capital Account Liberalisation Help More Than it Hurts? NBER Working paper No. 8414.

Asteriou, D., \& Hall S.G. (2007). Applied Econometrics: A Modern Approach using Eviews and Microfit. New York: Palgrave Macmillan.

Calderón, C., \& Liu L. (2003). The Direction of Causality between Financial Development and Economic Growth. Central Bank of Chile, Working Paper No. 184,

Chen, J., \& Quang T. (2012). International Finnacial Integration and Economic Growth: New Evidence on Threshold Effects. Paris School of Economics, Working Paper No. 30.

Dickey, D. A., \& Fuller W. A. (1979). Testing of Unit Roots in Seasonal Time Series. Journal of $\begin{array}{llll}\text { American Statistical } & \text { 39sociation, 385), }\end{array}$ http://dx.doi.org/10.1080/01621459.1984.10478057

Edison, H. J., Levine R. Ricci L., \& SloK T. (2002). International Financial Integration and Economic Growth. Journal of International Money and Finance, 21(6), 749-776. http://dx.doi.org/10.1016/S0261-5606(02)00021-9

Eichengreen, B. J. (2001). Capital Account Liberalization: What do the Cross-Country Studies tell us? World Bank Economic Review, 15(3), 341-366. http://dx.doi.org/10.1093/wber/15.3.341

Engle, R. F., \& Granger C. W. J. (1987). Co-integration and Error Correction: Representation, Estimation, and testing. Econometrica 55(2), 251-276. http://dx.doi.org/10.2307/1913236

Engle, R. F., \& Granger C. W. J. (1991). Long-Run Economic Relationship, Readings in Cointegration. Oxford University Press.

Fase, M. M. G., \& Abma R. C. N. (2003). Financial Environment and Economic Growth in Selected Asian Countries. Journal of Asian Economics 14(1), 11-21. http://dx.doi.org/10.1016/S1049-0078(02)00237-3

Fischer, S. (1997). Capital Account Liberalization and the Role of the IMF. IMF Seminar, Asia and the IMF.

Granger, C. W. J. (1981). Some Properties of Time series Data and their Use in Econometric Model Specification. Journal of Econometrics 16(1), 121-30. http://dx.doi.org/10.1016/03044076(81)90079-8

Gregorio, J, D. (1999). Financial Integration, Financial Development and Economic Growth. Estudio de Economia, 26(2), 137-161.

Hoxa, I., Kalemli-Ozcan S., \& Vollrath D. (2009). How Big Are The Gains From International Financial Integration? NBER Working Paper No. 14636. 
Johansen, S. (1991). Estimation and Hypothesis Testing of Cointegration Vectors in Gaussian Vector Autoregressive Model. Econometrica 59(6), 1551-1580. http://dx.doi.org/10.2307/2938278

Johansen, S. (1992). Determination of Cointegration Rank in the Presence of a Linear Trend. Oxford Bulletin of Economics and Statistics 54(3), 383-397. http://dx.doi.org/10.1111/j.14680084.1992.tb00008.x

Johansen, S., \& Juselius k. (1990). The Maximum Likelihood Estimation and Inference in Cointegration- with Application to Demand for Money. Oxford Bulletin of Economics and Statistics, 52(2), 169-210. http://dx.doi.org/10.1111/j.1468-0084.1990.mp52002003.x

Kim, D-H., Lin S-C., \& Suen Y-B. (2012). Dynamic Effects of Financial Openness on Economic Growth and Macroeconomic Uncertainty. Emerging Markets Finance and Trade 48(1), 25-54. http://dx.doi.org/10.2753/REE1540-496X480102

Klein, M. W., \& Olivei, G. P. (2008). Capital Account Liberalization, Financial Depth and Economic Growth. Journal of International Money and Finance, 27(6), 861-875.

Kose, M. A., Prasad E., Rogoff K., \& Wei S. J. (2006). Financial Globalisation: A Reappraisal. NBER Working Paper, 12484.

Kraay, A. (1998). In Search of the Macroeconomic Effects of Capital account Liberalisation. The World Bank Group. Retrieved from siteresources.worldbank.org/.../22237_CALMacroEFFECTS_Manuscript.pdf

Krugman, P. (1993). International Finance and Economic Development. In Albberto Giovanni (Ed.) Finance and Development: Issues and Experience pp. 11-24 Cambridge: Cambridge University Press. http://dx.doi.org/10.1017/CB09780511983290.003

Lane, P. R., \& Milesi-Ferretti G. M.(2003). International Financial Integration. IMF Staff Papers 50, 82-113. http://dx.doi.org/10.5089/9781451850901.001

Lane, P. R. \& Milesi-Ferretti G. M. (2012) Dataset constructed for the period 1970-2011 in the updated and extended version of "External Wealth of Nations Mark II". Retrieved from http://www.philplane.org/EWN.html

Levine, R. (2001). International Financial Liberalisation and Economic growth. Review of International Journal, 8(4), 688-702.

Mahajan, N., \& Verma S. (2014). Financial Development and Economic Growth: A Case of Indian Economy. International Journal of Economics, Finance and Management, 3(1), 15-21.

Masten, A. B., Coricelli F., \& Masten I. (2008). Non-Linear Growth Effects of Financial Development: Does Financial Integration Matter. Journal of International Money and Finance, 27(2), 295-313. http://dx.doi.org/10.1016/j.jimonfin.2007.12.009

Masten, A. B., Coricelli F., \& Masten I. (2011). Financial Integration and Financial Development in Transition Economies: What Happens During Financial Crisis. Economics and Business Review, 13(1-2), 119-137.

Mendoza, E. G., Quadrini V., \& Rios-Rull J-V. (2007). Financial Integration, Financial Deepness and Global Imbalances. NBER Working Paper No. 12909.

Osada, M., \& Saito M. (2010). Financial Integration and Economic Growth: An Empirical Analysis Using International Panel Data from 1974-2007. Bank of Japan, Working Paper No. 10-E-5.

Phillips, P. C. B., \& Perron P. (1988). Testing for a Unit Root in Time Series Regression. Biometrica, 75: 335-46. http://dx.doi.org/10.1093/biomet/75.2.335 
International Financial Integration and Economic Growth in India: An Empirical Investigation

Prasad, E. S., Rogoff K., Wei S-J., \& Kose M. A. (2003). Effects of Financial Globalisation on Developing Countries: Some Empirical Evidence. IMF Occasional Paper No. 220.

Ray, S. (2012). Causal Linkage between International Financial Integration and Economic Growth: Evidence from Post Globalised Indian Scenario. Advances in Asian Social Sciences, 3(4), 739-750.

Schularick, M., \& Steger T. M. (2006).Does Financial Integration Spur Economic Growth?: New Evidence from the First Era of Financial Globalisation. CESifo Working Paper Series 1691.

Stiglitz, J. E. (2003). Globalization and Its Discontents. New York: Norton.

Verma, S., \& Arora R. (2010). Does the Indian Economy Support Wagner's Law? An Econometric Analysis. Eurasian Journal of Business and Economics, 3 (5), 77-91.

\section{Appendix Table}

\section{Results of Principal Component Analysis}

\begin{tabular}{ccclcc}
\hline PC & $\begin{array}{c}\text { Eigen } \\
\text { Values }\end{array}$ & $\begin{array}{c}\text { Proportion } \\
\text { of Variance }\end{array}$ & \multicolumn{1}{c}{ Variables } & $\begin{array}{c}\text { Principal } \\
\text { Component }\end{array}$ & $\begin{array}{c}\text { Factor } \\
\text { Loadings }\end{array}$ \\
\hline 1 & 4.179 & .6964 & Total Banking Business & .978 & .681 \\
\hline 2 & 1.523 & .2537 & Credit Deposit Ratio & .499 & .204 \\
\hline 3 & .233 & .0389 & Rate of Monetization & .975 & .678 \\
\hline 4 & .051 & .0085 & Value Traded Ratio & .904 & .629 \\
\hline 5 & .012 & .0020 & Turn Over Ratio & .552 & .203 \\
\hline 6 & .002 & .0004 & Ratio of Public Sector Credit to GDP & .950 & .661 \\
\hline
\end{tabular}

Source: Authors' Calculations 